\title{
BAMBOO ASHES AS AN ECO-FRIENDLY ALTERNATIVE TO CEMENT - A SYSTEMATIC REVIEW ${ }^{1}$
}

\author{
Yuri Mariano Carvalho ${ }^{2}$ \\ Laura Ferreira Velasco
}

\begin{abstract}
Cement production impacts the environment from raw materials extraction to its industrialized production. Implementing supplementary cementitious materials (SCM) to replace cement is an economical and sustainable practice. Agricultural wastes, for example, represent a new source of SCM studied over the last decades, mainly due to its high generation around the world. Among the published review papers about agro-waste in civil construction, bamboo ashes (BA) appear secondary in large-scale studies. Thus, this work aimed to evaluate BA potential use in the construction industry as cement replacement by identifying their behavior in cementitious compounds and discovering the research gaps about this topic. We overviewed the published literature about concrete made with BA, synthesizing data about BA chemical composition and mechanical and physical characteristics of cementitious materials made with these ashes. We identified a preference for bamboo leaves ashes as SCM, potentially due to its high silica amount. However, other biological and environmental parameters that alter the bamboo chemical composition were not discussed in the papers. Concerning compressive strength, $90 \%$ of the studies with BA reported cementitious materials with a strength activity index acceptable for use. This review also identified an optimal percentage of cement replacement with BA ranging from $8 \%$ to $12 \%$ in concrete specimens. Concrete and mortar with BA also showed a lower density than the reference samples made only with cement. We concluded that BA are promising alternatives to replace cement since they provide desirable mechanical and physical characteristics to concrete and meet sustainability requirements. Besides that, we raised some topics that may guide future researches: (1) the natural and artificial parameters that affect BA composition; (2) BA chemical and physical behavior under microscopical conditions in cementitious composites; and (3) the economic advantages associated with replacing cement with BA.
\end{abstract}

Keywords: Cement substitutes. Addition. Artificial pozzolan. Sustainability. Supplementary cementitious materials.

\section{CINZAS DE BAMBU COMO ALTERNATIVA ECO-AMIGÁVEL AO CIMENTO - UMA REVISÃO SISTEMÁTICA}

\section{RESUMO}

A produção de cimento impacta o meio ambiente desde a extração de matérias-primas até sua produção industrializada, o que reforça a demanda por materiais cimentícios suplementares

\footnotetext{
${ }^{1}$ How to cite this paper: CARVALHO, Y. M.; VELASCO, L. F. Bamboo ashes as an eco-friendly alternative to cement - a systematic review. ForScience, Formiga, v. 9, n. 2, e00889, jul./dez. 2021. DOI: 10.29069/forscience.2021v9n1.e889.

2 Corresponding author: Yuri Mariano Carvalho, e-mail: yuri.mariano@engenharia.ufjf.br.
} 
(MCS) para substituir, mesmo que parcialmente, o uso do cimento. Os resíduos agrícolas, por exemplo, são um bom exemplo de MCS estudado nas últimas décadas, principalmente devido à sua alta geração em todo o mundo. Dentre os artigos de revisão publicados sobre o uso de resíduos agrícolas na construção civil, as cinzas de bambu figuram apenas como subtópico em estudos maiores. Logo, esse trabalho objetivou avaliar o potencial do uso de cinzas de bambu na indústria da construção civil como substituinte parcial ao cimento identificando seu comportamento em compostos cimentícios e sugerindo temas para pesquisas futuras. Esta revisão sistemática fornece uma visão geral da literatura publicada sobre argamassas e concretos feito com cinzas de bambu, sintetizando dados sobre a composição química dessas cinzas e as características mecânicas e físicas dos materiais cimentícios feitos com elas. Identificou-se uma preferência pelo uso de cinzas de bambu advindas da calcinação das folhas dessa planta, potencialmente devido ao seu alto teor de sílica. No entanto, existem parâmetros biológicos e ambientais que alteram a composição química do bambu e que não são discutidos pelos artigos. Quanto à resistência, 90\% dos estudos que empregaram cinzas de bambu reportaram à resistência compressão admissível para uso em construções. Levantou-se, também, que a porcentagem ideal de substituição de cimento por cinzas de bambu varia de $8 \%$ a $12 \%$ em amostras de concreto. Os materiais cimentícios com cinzas de bambu também apresentaram densidade menor que a das amostras de referência feitas apenas com cimento. Conclui-se pelo estudo que as cinzas de bambu são alternativas promissoras para substituir parcialmente o cimento visto que elas proporcionam boas características mecânicas e físicas ao concreto e atendem a demandas sustentáveis. Além disso, foram levantadas lacunas na literatura que podem guiar futuras pesquisas, quais sejam: (1) os parâmetros naturais e artificiais que afetam a composição química das cinzas de bambu; (2) o comportamento químico e físico de cinzas de bambu em compósitos cimentícios sob condições microscópicas; e (3) as vantagens econômicas associadas a substituir parcialmente cimento por cinzas de bambu.

Palavras-chave: Substitutos do cimento. Adição. Pozolana artificial. Sustentabilidade. Materiais cimentícios suplementares.

\section{INTRODUCTION}

Concrete is the most widely employed material in the world, being used from road construction to skyscrapers. However, cement production is responsible for $5 \%$ of the annual anthropogenic global carbon dioxide $\left(\mathrm{CO}_{2}\right)$ production (CROW, 2008) - each ton of concrete produced generates about 1 ton of $\mathrm{CO}_{2}$ (RODIER et al., 2019). To reduce the detrimental impacts of the cement industry, researchers investigate an alternative to cement known as supplementary cementitious materials (SCM) - a vast group of materials that possess cementing properties (DAMTOFT et al., 2008) and also contribute to the reduction of environmental problems (CROW, 2008; DAMTOFT et al., 2008; TAMBICHIK et al., 2018; DUCHESNE, 2020).

Agricultural wastes, for example, can be used as SCM, as shown by many researchers. Besides having pozzolanic properties, which favors their application as cement replacement (MO et al., 2016; LUHAR; CHENG; LUHAR, 2019; RODIER et al., 2019), agricultural waste attract interest due to its great generation around the world, only smaller than that of industrial 
waste (KAZA et al., 2018). Among the investigated agro-wastes in civil construction, there are corn cob ash (OLAFUSI; OLUTOGE, 2012; MUJEDU; ADEBARA; LAMIDI, 2014), elephant grass ash (CORDEIRO; SALES, 2015; NAKANISHI et al., 2016), rice husk ash (HABEEB; MAHMUD, 2010; ABU BAKAR; RAMADHANSYAH; MEGAT AZMI, 2011; DHENGARE et al., 2019; LI et al., 2019), sugarcane bagasse ash (SHAFIQ et al., 2018; DHENGARE et al., 2019; YADAV et al., 2020), and wheat straw ash ( MEMON et al., 2018; AMIN et al., 2019). These plants belong to the Poaceae family and are known to accumulate silica during their lifetime, thus presenting silicon $(\mathrm{Si})$ content higher than calcium (Ca) content (MA; TAKAHASHI, 2002).

Like other agricultural wastes from the Poaceae family, bamboo ashes can also be an alternative for cement replacement. Distributed worldwide through about 1600 species (HIDALGO-LÓPEZ, 2003), bamboo fastest-growing among other plants - even without fertilizers and pesticides - and its great $\mathrm{O}_{2}$ release - which is $35 \%$ greater than trees (MOSLEY, 2013) - supports bamboo use in comparison to other plants. Although its many advantages, there is no published paper until now concerned only to review the use of bamboo ashes as $\mathrm{SCM}$ in concrete production and displays its pros and cons. Chemical and physical properties of concrete made with bamboo ashes usually appear secondary in large-scale reviews of agrowaste materials used in civil construction (MO et al., 2016; MARTIRENA; MONZÓ, 2018; LUHAR; CHENG; LUHAR, 2019).

Therefore, to fill this gap, this systematic review aims to answer the research question: "what are the chemical properties of bamboo ashes, and what are the mechanical and physical properties of concrete and mortar samples containing bamboo ashes as partial cement replacement?". By evaluating bamboo ashes potential use as partial cement replacement in the construction industry, this work will contribute to the scientific community synthesizing the literature regarding using bamboo ashes as SCM and rising new research topics.

\section{MATERIAL AND METHODS}

The systematic review protocol (Figure 1) was undertaken following the recommendations of Carvalho (2019). We established keywords and inclusion and exclusion criteria based on an exploratory evaluation of the published literature about agro-waste in civil construction (since there is no review that specifically approaches bamboo as cement replacement). We decided to include only original papers published until the end of 2019 to give an assertive synthesis about what has been studied until this year. We accessed six 
databases (EBSCO, Ei Compendex, Google Scholar, Pro-Quest, ISI Web of Science, ScienceDirect, and Scopus) to achieve a broader view on bamboo ashes as SCM, using the search string "bamboo AND ash AND (concrete OR mortar)".



Figure 1 - Literature review process. The colors indicate the accepted (green) and excluded (red) studies per review stage ( $\mathrm{n}$ is the number of records)

Source: The authors (2021).

We used the StArt tool (SILVA et al., 2016) to improve the selection of the papers. The software (developed by the Laboratory of Research on Software Engineering (LaPES) of the Federal University of São Carlos (UFSCar), São Paulo, Brazil) supports planning, evaluation (inclusion and exclusion of papers), and summary steps of the systematic review. The tool is free and available for download on the laboratory website. Except for the papers manually selected from Google Scholar, we uploaded the records from the other databases (in RIS and BibTeX form) to the StArt tool to remove duplicates and to optimize titles and abstracts evaluation.

When applying the inclusion and exclusion criteria, we included the records accepted by at least one researcher for the next steps of the review to avoid personal bias. The selected papers should contribute with at least one of the three main categories approached in this review: (1) chemical composition of bamboo ashes and (2) mechanical and (3) physical characteristics of concrete and mortar made with bamboo ashes. Afterward, we collected, synthesized, and analyzed the relevant information of the selected papers. 


\section{RESULTS AND DISCUSSION}

\subsection{Chemical composition}

Bamboo ashes are produced by calcining the plant culm (ABOLUWARIN et al., 2017; RODIER et al., 2017; DAVID; HASSAN, 2018; MUJEDU et al., 2018; IKEAGWUANI et al., 2019) or its leaves (DWIVEDI et al., 2006; FRÍAS et al., 2012; ARUM; IKUMAPAYI; ARALEPO, 2013; ADEMOLA; BUARI, 2014; UMOH; UJENE, 2014; KOLAWOLE; OLUSOLA; ATA, 2015; UMOH; ODESOLA, 2015; DHINAKARAN; CHANDANA, 2016; IKUMAPAYI, 2017; OLONADE; JAJI; ADEKITAN, 2017; OLUTOGE; OLADUNMOYE, 2017; MORAES et al., 2019; ONIKEKU et al., 2019; RODIER et al., 2019) (Figure 1).

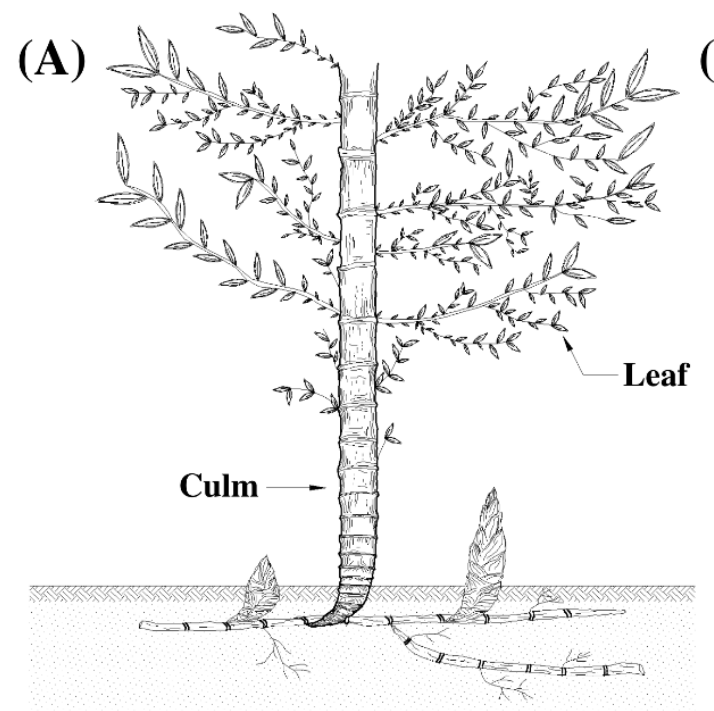

(B)

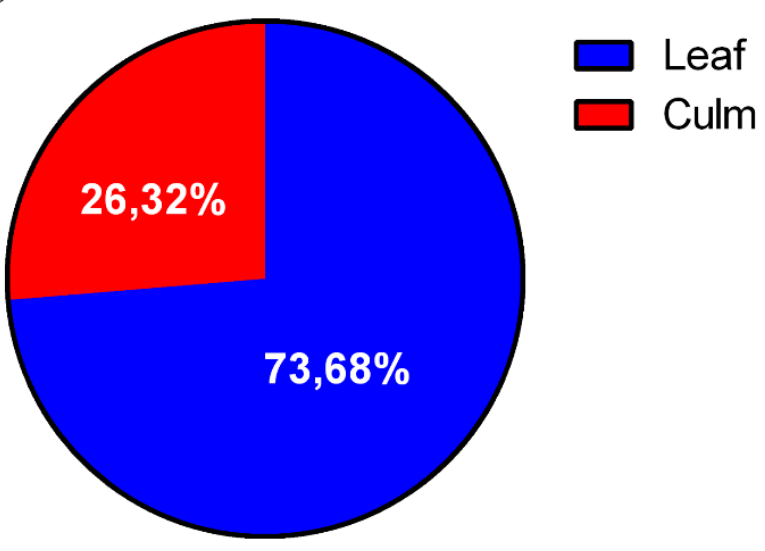

Figure 2 - (A) Schematic representation of a bamboo plant and (B) recurrence of bamboo parts calcined for ash production in literature

Source: The authors (2021).

The preference for producing ashes from bamboo leaves can be associated with the high amount of silica $\left(\mathrm{SiO}_{2}\right)$ accumulated in the leaves along the plant life cycle (MOTOMURA; HIKOSAKA; SUZUKI, 2008). After calcining the leaves, $\mathrm{SiO}_{2}$ corresponds to about $70 \%$ of the ashes' chemical composition (Table 1). 
Table 1 - Bamboo leaves ashes chemical composition

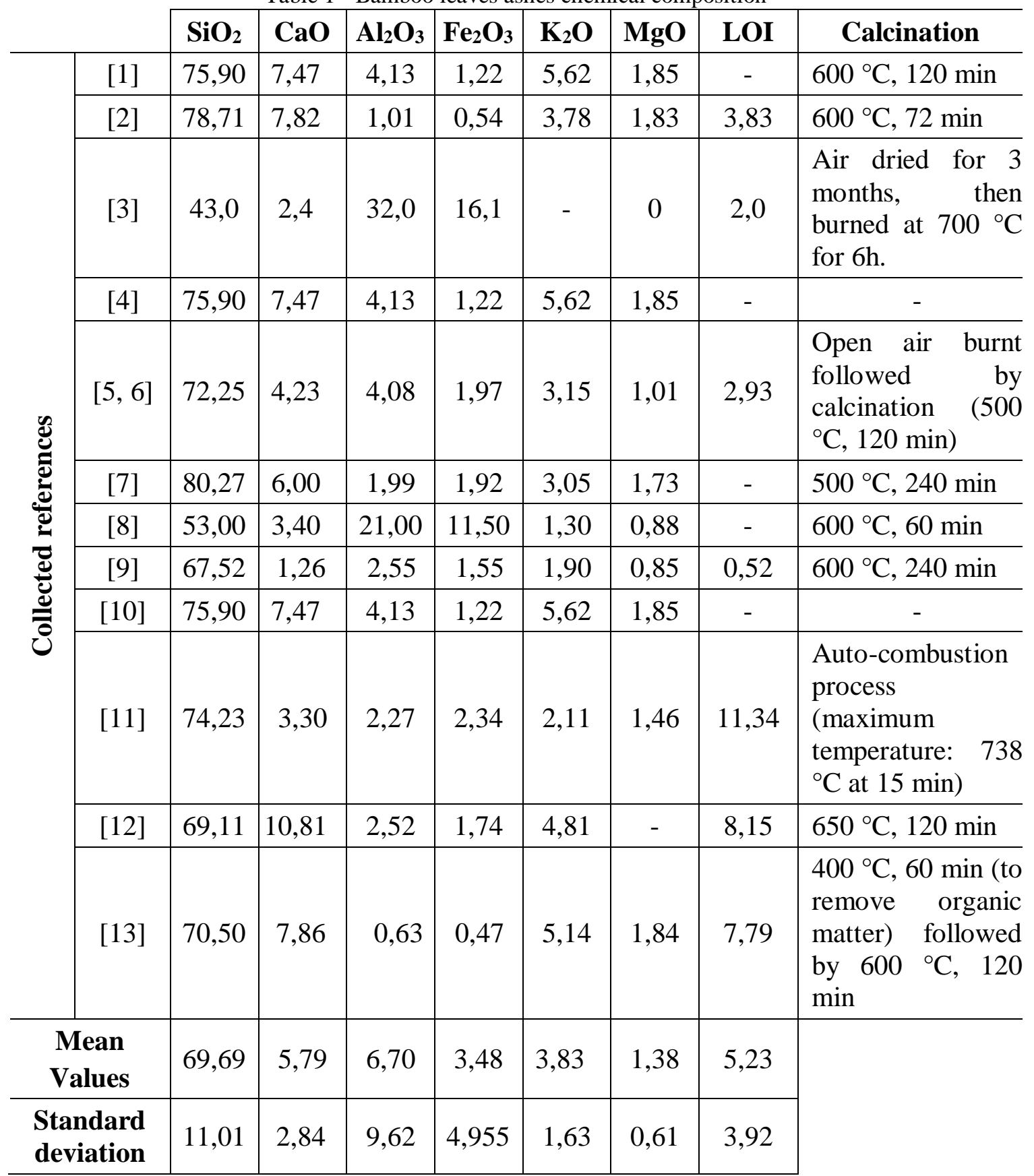

Mean and standard values were calculated considering only the filled cells. Abbreviations: LOI - loss on ignition Source: [1] Dwivedi et al. (2006); [2] Frías et al. (2012); [3] Arum, Ikumapayi and Aralepo (2013); [4] Ademola and Buari (2014); [5] Umoh and Ujene (2014); [6] Umoh and Udesola (2015); [7] Dhinakaran and Chandana (2016); [8] Ikumapayi (2017); [9] Olonade, Jaji and Adekitan (2017); [10] Olutoge and Oladunmoye (2017); [11] Moraes et al. (2019); [12] Onikeku et al. (2019); [13] Rodier et al. (2019).

Great amounts of silica contribute to produce ashes in accordance with American (AMERICAN SOCIETY FOR TESTING AND MATERIALS, 2019) and Brazilian (ASSOCIAÇÃO BRASILEIRA DE NORMAS TÉCNICAS, 2014) standards - which state that artificial pozzolans must have $70 \%$ of their chemical composition formed by $\mathrm{SiO}_{2}$, aluminum oxide $\left(\mathrm{Al}_{2} \mathrm{O}_{3}\right)$, and $\mathrm{Fe}_{2} \mathrm{O}_{3}$. However, other parameters must be attended to classify a material as 
a pozzolanic ash such as (AMERICAN SOCIETY FOR TESTING AND MATERIALS, 2019; ASSOCIAÇÃO BRASILEIRA DE NORMAS TÉCNICAS, 2014): an alkalis content lesser than $1.5 \%$ (high alkali content increase the possibility of an alkali-silica reaction, which can lead to concrete crack (NEVILLE, 2016)), a sulfuric anhydride $\left(\mathrm{SO}_{3}\right)$ content lesser than 5\% (even in small amounts, $\mathrm{SO}_{3}$ can delay the binder setting time (AMARAL, 2016)), and a loss on ignition (LOI) lesser than 10\% (high LOI values may suggest high amounts of organic matter and carbonate contents of sediments in ashes, even though previous report indicates other parameters that may influence on results (HEIRI; LOTTER; LEMCKE, 2001)). Regarding those parameters, we can discard the ashes produced by Olonade, Jaji e Adekitan (2017) $\left(\mathrm{Na}_{2} \mathrm{O}\right.$ $=1.9 \%)$ and Moraes et al. $(2019)(\mathrm{LOI}=11.34 \%)$.

Regarding bamboo culm ashes, only Rodier et al. (2017) and Mujedu et al. (2018) reported its chemical composition - and they had contrasting findings. Rodier et al. (2017) calcined bamboo culm at $600{ }^{\circ} \mathrm{C}$ with a heating rate of $30{ }^{\circ} \mathrm{C} / \mathrm{min}$ for $180 \mathrm{~min}$ and obtained a sum of $\mathrm{SiO}_{2}, \mathrm{Al}_{2} \mathrm{O}_{3}$, and $\mathrm{Fe}_{2} \mathrm{O}_{3}$ equal to $69,05 \%$, which is very close to the one recommended by ABNT NBR 12653:14 (ASSOCIAÇÃO BRASILEIRA DE NORMAS TÉCNICAS, 2014) and ASTM C 618:19 (AMERICAN SOCIETY FOR TESTING AND MATERIALS, 2019). Mujedu et al. (2018), in their turn, obtained bamboo ashes with a sum lesser than $40 \%\left(\mathrm{SiO}_{2}=\right.$ $21,14 \% ; \mathrm{Al}_{2} \mathrm{O}_{3}=0,08 \% ; \mathrm{Fe}_{2} \mathrm{O}_{3}=16,46 \%$ ) by open burning the plant culm. The researchers opted for this method because they were searching for an economical way to encourage the replacement of cement by bamboo ashes in rural areas. This difference in chemical composition is strongly related to the calcination conditions; therefore, to draw adequate conclusions about bamboo culm ashes use as SCM, new studies should evaluate the ashes chemical composition and its pozzolanic reactivity under different calcination temperature and duration.

In general, differences in chemical composition of bamboo plants occurs according to biological and environmental parameters. Plant species (VASSILEV et al., 2010; COLLIN et al., 2012; HELANDER et al., 2013), plant part (MA; TAKAHASHI, 2002; VASSILEV et al., 2010; COLLIN et al., 2012), plant age (MA; TAKAHASHI, 2002; VASSILEV et al., 2010), harvesting time and technics, and growing conditions, such climate and relief of the plantation region (MA; TAKAHASHI, 2002; VASSILEV et al., 2010; UMEMURA; TAKENAKA, 2014), contribute for chemical composition diversity. However, the reviewed papers only reported the calcined bamboo-part and the geographical site where the plant was collected, with few exceptions (DWIVEDI et al., 2006; ADEMOLA; BUARI, 2014; DHINAKARAN; CHANDANA, 2016; IKUMAPAYI, 2017) that did not specify the bamboo origin. The 
accessed studies of bamboo ashes as SCM lacks data about the bamboo species, its average age, and the harvest season/process, which implies some barriers for results generalization.

Researches (VILLAR-COCIÑA et al., 2011, 2018) also reported variation in calcination temperature and duration as a criterion correlated to bamboo ashes chemical composition. Certain amounts of heat can turn bamboo leaves in siliceous ashes with more than $70 \%$ of $\mathrm{SiO}_{2}$ in its chemical composition (DWIVEDI et al., 2006; VILLAR-COCIÑA et al., 2011; FRÍAS et al., 2012; UMOH; UJENE, 2014; ROSELLÓ et al., 2015; UMOH; ODESOLA, 2015; DHINAKARAN; CHANDANA, 2016; OLUTOGE; OLADUNMOYE, 2017; MORAES et al., 2019; RODIER et al., 2019) and, also, reduce potassium (K) and chloride (Cl) levels in the ashes (ROSELLÓ et al., 2015). As well as in sugarcane bagasse ashes (YADAV et al., 2020), temperature and duration of the calcination process directly implies the pozzolanic reactivity and the amorphous silica content in the ashes (VILLAR-COCIÑA et al., 2018).

Previous studies with sugarcane bagasse (CORDEIRO; TOLEDO FILHO; FAIRBAIRN, 2009) and rice rusk (JAYA et al., 2013) estimated optimum temperature and duration conditions to produce the ashes. Concerning BLA, studies pointed the controlled calcining of bamboo leaves at $500-600{ }^{\circ} \mathrm{C}$ for $120 \mathrm{~min}$ as a suitable condition to get a totally amorphous material with high pozzolanic reactivity (VILLAR-COCIÑA et al., 2011, 2018). However, other research reported greater silica content by calcining bamboo leaves at $850{ }^{\circ} \mathrm{C}$ for 60 min (ROSELLÓ et al., 2015). In this context, further studies must evaluate the pozzolanic reactivity of bamboo ashes under different calcining conditions; the energy demanded to produce the ashes should also be analyzed to avoid creating a SCM with a high carbon footprint.

Therefore, developing a methodology that recognizes a higher number of variables associated with bamboo chemical composition, and ensures the research reproducibility, can be a promising topic for future studies.

\subsection{Compressive strength}

Most of the accepted studies analyzed the compressive strength of the cementitious materials with bamboo ashes. Other properties, such as tensile and flexural strength, were not very explored in the papers; therefore, we did not approach them in this review.

In general, the optimal percentage for cement replacement with bamboo ashes, which corresponds to greater compressive strength, ranged from $8 \%$ to $12 \%$ for concrete. However, the papers did not show an established pattern for mortars since bamboo ashes optimal replacements ranged from 5 to $20 \%$ (Table 2). 
Table 2 - Compressive strength of concrete and mortar samples made with an optimal replacement percentage of cement by bamboo ashes compared to reference samples (made only with cement) at 28 days. The optimal replacement percentage indicates the replacement value that reported better strength performance

\begin{tabular}{c|c|c|c|c|c|c}
\hline \multirow{2}{*}{$\begin{array}{c}\text { Collected } \\
\text { references }\end{array}$} & Application & $\begin{array}{c}\text { Calcined } \\
\text { Bamboo part }\end{array}$ & $\begin{array}{c}\text { Optimal } \\
\text { replacement } \\
(\%)\end{array}$ & \multicolumn{2}{c|}{$\begin{array}{c}\text { Compressive } \\
\text { Strength (MPA) }\end{array}$} & Strength \\
\cline { 5 - 6 } & & & & Activity \\
& & With BA & 0\% BA & Index (\%) \\
\hline$[1]$ & Mortar & Culm & 15 & 2,05 & 1,32 & 155,30 \\
\hline$[2]$ & Mortar & Leaves & 5 & 19,1 & 14,9 & 128,19 \\
\hline$[3]$ & Concrete & Leaves & 8 & 17,7 & 15,2 & 116,45 \\
\hline$[4]$ & Mortar & Leaves & 20 & 43,0 & 37,0 & 116,22 \\
\hline$[5]$ & Mortar & Leaves & 20 & 49,2 & 43,5 & 113,10 \\
\hline$[6]$ & Mortar & Culm & $10^{*}$ & 71,0 & 63,0 & 112,70 \\
\hline$[7]$ & Concrete & Leaves & 10 & 28,5 & 26,9 & 15,95 \\
\hline$[8]$ & Mortar & Leaves & $10-20$ & 70,0 & 70,7 & 99,01 \\
\hline$[9]$ & Concrete & Culm & 10 & 23,5 & 24,5 & 95,92 \\
\hline$[10]$ & Concrete & Leaves & 10 & 28,6 & 30,2 & 94,70 \\
\hline$[11]$ & Concrete & Leaves & 5 & 23,1 & 25,4 & 90,94 \\
\hline$[12]$ & Concrete & Leaves & 15 & 20,4 & 22,7 & 89,87 \\
\hline$[13]$ & Concrete & Leaves & 10 & 21,0 & 23,6 & 88,98 \\
\hline$[14]$ & Mortar & Leaves & $20^{*}$ & 60,0 & 70 & 85,71 \\
\hline$[15]$ & Concrete & Leaves & 5 & 19,9 & 24 & 82,92 \\
\hline$[16]$ & Mortar & Culm & 5 & 11,8 & 14,3 & 85,52 \\
\hline$[17]$ & Mortar & Culm & 4 & 4,0 & 5,89 & 67,91 \\
\hline$[18]$ & Concrete & Leaves & 10 & 18,3 & 29,2 & 62,67 \\
\hline
\end{tabular}

*researchers only investigated one cement replacement percentage by bamboo ashes. Abbreviations: BA-bamboo ashes. Source: [1] Aboluwarin et al. (2017); [2] Umoh and Odesola (2015); [3] Ikumapayi (2017); [4] Rodier et al. (2019); [5] Moraes et al. (2019); [6] Rodier et al. (2017); [7] Onikeku et al. (2019); [8] Frías et al. (2012); [9] Ikeagwuani et al. (2019); [10] Olutoge and Oladunmoye (2017); [11] Umoh and Ujene (2014); [12] Dhinakaran and Chandana (2016); [13] Ademola and Buari (2014); [14] Dwivedi et al. (2006); [15] Olonade, Jaji and Adekitan (2017); [16] Mujedu et al. (2018); [17] David and Hassan (2018); [18] Kolawole, Olusola and Ata (2015).

Presumably, the standardization lack in bamboo ashes production can be correlated with the differing results in compressive strength since it implies different chemical and physical compositions of the ashes (Figure 3). Other variables - such as water-cement ratio (MEHTA; MONTEIRO, 2006; NATARAJAN; KARUPPIAH, 2014; CHEN et al., 2018), cement type (MEHTA; MONTEIRO, 2006), additions (MEHTA; MONTEIRO, 2006; NATARAJAN; KARUPPIAH, 2014), and curing conditions (MEHTA; MONTEIRO, 2006) - also need to be evaluated to improve the understanding of bamboo ashes effect in the mechanical behavior of cementitious materials. 


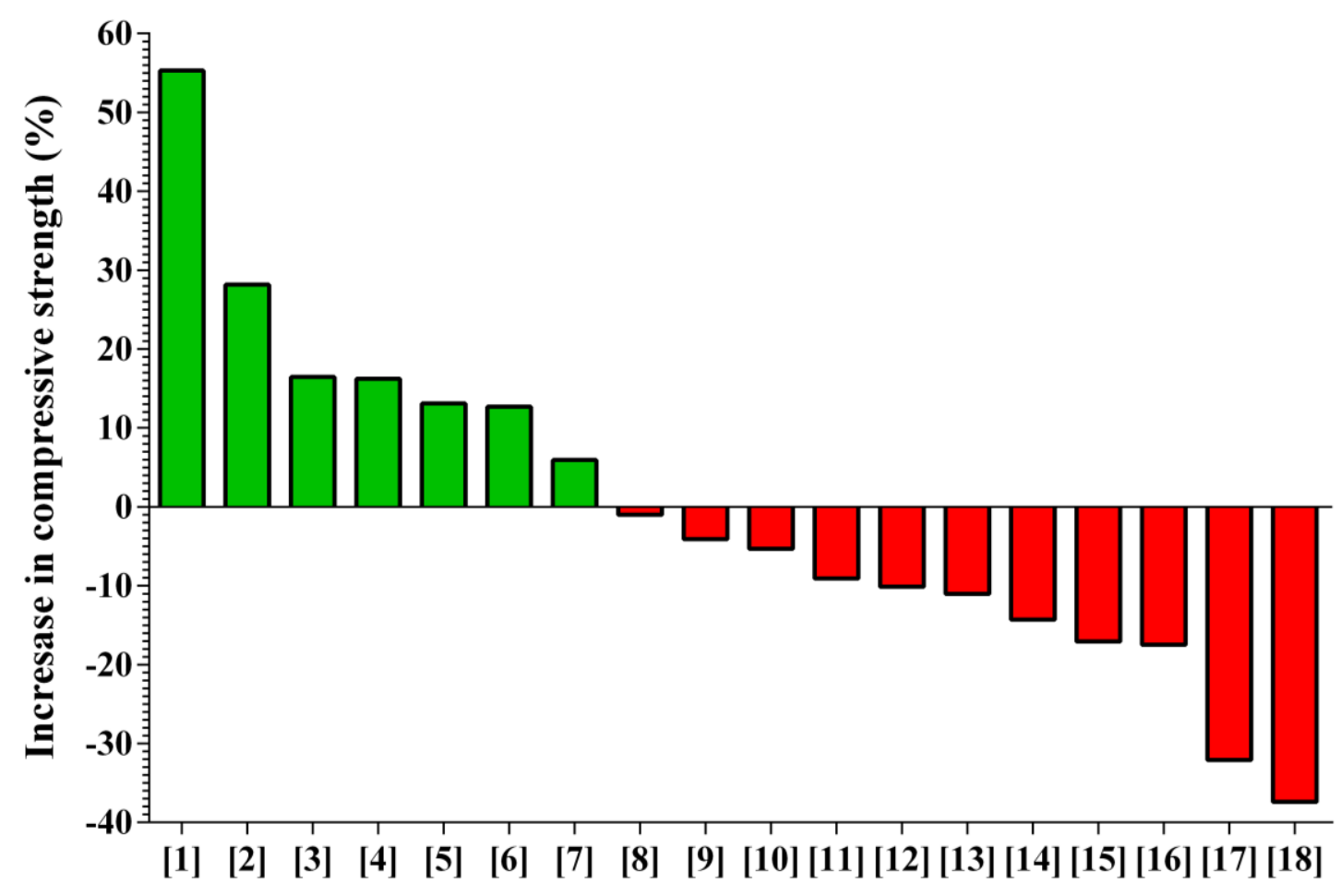

\section{References}

Figure 3 - Increase and decrease (percentage) in compressive strength of cementitious materials made with bamboo ashes in comparison to reference samples

Source: [1] Aboluwarin et al. (2017); [2] Umoh and Odesola (2015); [3] Ikumapayi (2017); [4] Rodier et al. (2019); [5] Moraes et al. (2019); [6] Rodier et al. (2017); [7] Onikeku et al. (2019); [8] Frías et al. (2012); [9] Ikeagwuani et al. (2019); [10] Olutoge and Oladunmoye (2017); [11] Umoh and Ujene (2014); [12] Dhinakaran and Chandana (2016); [13] Ademola and Buari (2014); [14] Dwivedi et al. (2006); [15] Olonade, Jaji and Adekitan (2017); [16] Mujedu et al. (2018); [17] David and Hassan (2018); [18] Kolawole, Olusola and Ata (2015).

The high amounts of $\mathrm{SiO}_{2}$ in bamboo ashes helps increasing the compressive strength of cementitious materials (IKUMAPAYI, 2017; MORAES et al., 2019; ONIKEKU et al., 2019; RODIER et al., 2019). According to Mehta and Monteiro (MEHTA; MONTEIRO, 2006), siliceous compounds are responsible for the formation of hydrates in a process called pozzolanic reaction. The reaction consists of slow lime production and subsequent consumption, which provides the mass hydration. Then, lime consumption results in the formation of hydrate compounds that commonly improve the performance of concrete. Those reactions contribute to later strength development in cementitious materials. Since the improvement in strength by pozzolanic materials is a slow process (MASSAZZA, 1993), the decrease in compressive strength at 28 days in some studies (DWIVEDI et al., 2006; FRÍAS et al., 2012; UMOH; UJENE, 2014; DHINAKARAN; CHANDANA, 2016; OLUTOGE; OLADUNMOYE, 2017) is an expected outcome that does not refute possible advantages of cement replacement with $\mathrm{BA}$.

The increase in compressive strength can also be related to the ashes fineness (RODIER et al., 2019). When pozzolanic particles are smaller than the cement, they fill the voids between 
cement grains and aggregates; consequently, the mixture becomes more compacted, improving the compressive strength in a phenomenon called filler effect (MOOSBERG-BUSTNES; LAGERBLAD; FORSSBERG, 2004). Moreover, the ashes fineness directly influences particle reactivity: smaller particles increase the dissolution rates of ashes, which increases the pozzolanic reaction and the later strength gain (ARVANITI et al., 2015).

However, Dhinakaran and Chandana (2016) reached lesser strength values in their tests even using ashes sieved below $90 \mu \mathrm{m}$, which is similar to Portland cement fineness. They associate this result with the addition of water in the mixture to obtain the same workability as concrete without bamboo ashes as SCM. Ashes with irregular shape (ABU BAKAR; RAMADHANSYAH; MEGAT AZMI, 2011; YADAV et al., 2020), high specific area (HABEEB; MAHMUD, 2010), high LOI content (THOMAS, 2013), high presence of carbon (ARUM; IKUMAPAYI; ARALEPO, 2013), or with porous structure (MEMON et al., 2018; YADAV et al., 2020) grant higher water demand when applied in concretes and mortars. Previous studies (HABEEB; MAHMUD, 2010; NAKANISHI et al., 2016) recommended using plasticizers as an alternative to reduce the water use in cementitious materials with agro-waste as SCM and to improve workability. Given that, we recommend that bamboo ashes must be analyzed under microscopic conditions to characterize and evaluate its potential use.

Despite the lack of a direct relationship between bamboo ashes as cement replacement and the compressive strength of cementitious samples, almost $90 \%$ of the researchers reported a strength activity index above $75 \%$ - which enables its use in constructions, following ASTM C 1709:18 test procedures (AMERICAN SOCIETY FOR TESTING AND MATERIALS, 2018). Therefore, if meeting this requirement, the use of pozzolanic material is acceptable and can be very advantageous, economically and environmentally.

\subsection{Physical Characteristics}

Table 3 summarizes physical characteristics of cementitious materials (samples made with bamboo ashes at optimal rate and the ones made only with cement) related to void index and ashes particles size (water absorption, porosity, and density). 
Table 3 - Physical characteristics of concrete and mortars made with an optimal replacement percentage of cement by bamboo ashes compared to reference samples (made only with cement)

\begin{tabular}{|c|c|c|c|c|c|c|c|c|c|c|}
\hline \multirow{2}{*}{$\begin{array}{l}\text { Collected } \\
\text { references }\end{array}$} & \multirow{2}{*}{$\begin{array}{c}\text { Ashes } \\
\text { maximum } \\
\text { size }(\mathbf{m m})\end{array}$} & \multicolumn{3}{|c|}{$\begin{array}{c}\text { Water absorption } \\
\text { at } 28 \text { days } \\
\end{array}$} & \multicolumn{3}{|c|}{ Porosity (\%) } & \multicolumn{3}{|c|}{ Density (g/cm $\left.{ }^{3}\right)$} \\
\hline & & $\begin{array}{l}\mathbf{0 \%} \\
\text { BA }\end{array}$ & \begin{tabular}{|c|} 
With \\
BA
\end{tabular} & $\begin{array}{c}\text { Increase } \\
\text { rate }\end{array}$ & $\begin{array}{l}\text { 0\% } \\
\text { BA }\end{array}$ & $\begin{array}{c}\text { With } \\
\text { BA }\end{array}$ & $\begin{array}{c}\text { Increase } \\
\text { rate }\end{array}$ & $\begin{array}{l}\text { 0\% } \\
\text { BA }\end{array}$ & $\begin{array}{c}\text { With } \\
\text { BA }\end{array}$ & $\begin{array}{c}\text { Increase } \\
\text { rate }\end{array}$ \\
\hline$[1]$ & 0,075 & $24 \mathrm{~g}$ & $18 \mathrm{~g}$ & $-25,00 \%$ & \multicolumn{3}{|c|}{-} & 4,04 & 1,82 & $-10,78 \%$ \\
\hline$[2]$ & 0,075 & $4,18 \%$ & $4,80 \%$ & $0,62 \%$ & 6,52 & 7,2 & $0,68 \%$ & 2,30 & 2,00 & $-13,04 \%$ \\
\hline$[3]$ & $\begin{array}{c}0,300 \text { (then } \\
\text { milled) }\end{array}$ & \multicolumn{3}{|c|}{ 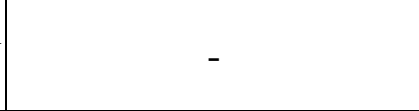 } & 27,6 & 26,1 & $-1,50 \%$ & \multicolumn{3}{|c|}{-} \\
\hline$[4]$ & 0,150 & $7,38 \%$ & $4,21 \%$ & $-3,17 \%$ & 15,6 & 8,3 & $-7,30 \%$ & 2,75 & 2,56 & $-6,91 \%$ \\
\hline [5] & 0,212 & \multicolumn{3}{|c|}{ 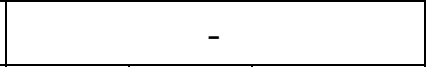 } & \multicolumn{3}{|c|}{ 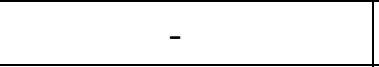 } & 2,64 & 2,58 & $-2,27 \%$ \\
\hline [6] & 0,045 & $2,60 \%$ & $1,30 \%$ & $-1,30 \%$ & \multicolumn{3}{|c|}{-} & \multicolumn{3}{|c|}{-} \\
\hline [7] & 0,090 & \multicolumn{3}{|c|}{-} & 6,2 & 7,8 & $1,60 \%$ & \multicolumn{3}{|c|}{-} \\
\hline [8] & 0,075 & $2,10 \%$ & $4,23 \%$ & $2,13 \%$ & 2,2 & 4,3 & $2,130 \%$ & 2,11 & 2,07 & $-1,90 \%$ \\
\hline [9] & - & $16 \mathrm{~g}$ & $13 \mathrm{~g}$ & $-16,88 \%$ & \multicolumn{3}{|c|}{-} & 2,38 & 2,29 & $-3,78 \%$ \\
\hline$[10]$ & - & \multicolumn{3}{|c|}{-} & \multicolumn{3}{|c|}{-} & 3,10 & 2,25 & $-27,42 \%$ \\
\hline
\end{tabular}

Abbreviations: BA - bamboo ashes. Source: [1] Aboluwarin et al. (2017); [2] Umoh and Odesola (2015); [3] Moraes et al. (2019); [4] Onikeku et al. (2019); [5] Olutoge and Oladunmoye (2017); [6] Umoh and Ujene (2014); [7] Dhinakaran and Chandana (2016); [8] Mujedu et al. (2018); [9] David and Hassan (2018); [10] Rodier et al. (2017).

Some authors obtained a decrease in water absorption, which may be attributed to the initial filling of voids by the bamboo ashes in the mixture (UMOH; UJENE, 2014; ONIKEKU et al., 2019). This phenomenon can occur due to the packing of particles (DAMINELI; PILLEGGI; JOHN, 2017), which consists of the successive filling of voids between larger particles by smaller ones. Using particles with different sizes decreases the void volume, thus reducing porosity and water absorption rate. Another explanation comes from the increase in chemical reactions (MEHTA; MONTEIRO, 2006): hydration reactions products fill the capillary void, which reduces porosity and, consequently, water absorption.

However, a few researchers obtained a small increase in water absorption, which they have associated with the porosity from the delay in the hydration reaction (UMOH; ODESOLA, 2015; DHINAKARAN; CHANDANA, 2016; MUJEDU et al., 2018). Initially, the reduction of the cement percentage in the mixture implies lesser initial hydration rates; this delay in calcium hydroxide releasing to react with bamboo ashes cause late calcium silicate hydrates formation, which increases porosity (UMOH; ODESOLA, 2015). Moreover - considering the lower pozzolanic reactivity at early time of hydration (SINGH et al., 2007) -, we could imply that the bamboo ashes only partially reacted at 28 days, allowing water to ingress into the samples. 
Properties as water absorption and porosity directly influence the durability of cementitious materials. The greater the porosity and water absorption, the lower the durability because of possible physical-chemical degradation promoted by water in concrete (MEHTA; MONTEIRO, 2006). Moreover, porosity also affects compressive strength by an inversely proportional relation: when the number of pores exceeds a specified limit, strength trends to zero (LIAN; ZHUGE; BEECHAM, 2011).

Concerning density, all researches reached lower values for concrete and mortars with bamboo ashes as cement replacement. Since bamboo ash has lower specific mass than cement, the use of ashes contributes to produce lighter specimens without changing volume (UMOH; ODESOLA, 2015; RODIER et al., 2017). As seen in lightweight concrete, using low-density materials reduce the load of structures, which permits to shorten structural elements size (LIBRE et al., 2011; ALTUN; AKTAŞ, 2013; VANDANAPU; KRISHNAMURTHY, 2018).

Further researches should investigate the influence of bamboo ashes on the physical properties of cementitious materials since the literature has fewer and contrasting results regarding materials characteristics such as ashes maximum size, water absorption, porosity, and density. This lack of data hindered us from inferring a substantial-conclusion about the effect of adding bamboo ashes as a partial substitute for cement in concrete and mortars. In general, the studies pointed that bamboo ashes can improve cementitious materials' durability by reducing their porosity and water absorption - two generally related properties. The ashes' lower density can also help to produce light concrete structures.

\section{CONCLUSIONS}

Bamboo ashes are an agro-waste material with few discussions in English scientific literature concerning its use and its properties as SCM. This study aimed to overview the publications about concrete made with bamboo ashes to evaluate their potential use in the construction industry as cement replacements.

We identified a preference for using bamboo leaves instead of other parts of the plant due to the silica accumulation in the leaves during the bamboo life-cycle. Due to their high silica content, bamboo ashes high pozzolanic activity, which supports their use as SCM. However, other biological and environmental parameters that affect the bamboo chemical composition were not approached in the raised studies, such as bamboo species, its average age, and its harvest season. Thus, we recommend additional research considering those parameters to identify the better conditions to produce a qualified SCM with bamboo ashes. 
Calcination temperature and duration, as well, directly imply the content of the oxide in bamboo ashes. Further studies must consider identifying the optimum values for temperature and duration of the bamboo calcination process to produce ashes with better properties as SCM.

Concerning compressive strength, the optimal cement replacement with bamboo ashes ranged from $8 \%$ to $12 \%$ for concrete since the samples achieved optimal strength values at 28 days in these percentages. Nonetheless, we recommend that future studies focus on determining the effect of bamboo ashes addition on concrete strength at advanced ages.

Regarding physical characteristics, concrete and mortar with bamboo ashes reported lower density than the reference samples made only with cement, which reduces the structural load. We also identified that making samples with bamboo ashes decreased their water absorption, highlighting those ashes' potential to improve cementitious materials' durability.

In general, the papers differed on bamboo ashes effects as SCM on mechanical and physical characteristics of cementitious materials. New research must identify the causes of these divergences in results and verify a relationship between ashes characteristics (chemical composition, microscopic behavior, particles fineness) and concretes and mortars properties (compressive strength, water absorption, porosity, density). Moreover, we suggest that further studies concentrate on determining the costs of implementing bamboo ashes as SCM, such as their availability to be applied on an industrial scale.

Therefore, this study achieved its aim of evaluating bamboo ashes potential use in the construction industry as SCM, such as their behavior in cementitious compounds and the gaps about this topic in literature. Thus, we contributed to the scientific community by synthesizing the published studies regarding using bamboo ashes as SCM. Besides, we proposed new research topics, which may encourage future research with bamboo ashes in civil construction, especially regarding their production and use on large scales and their potential to build a green economy.

\section{REFERENCES}

ABOLUWARIN, O. et al. Investigating the effect of bamboo trunk ash blended cement in engineering properties of mortar. International Journal of Science and Research, Raipur, Índia, v. 6, n. 7, p. 2037-2040, 2017. Disponível em: https://doi.org/10.21275/art20175631. Acesso em: 17 aug. 2020.

ABU BAKAR, B. H.; RAMADHANSYAH, P. J.; MEGAT AZMI, M. J. Effect of rice husk ash fineness on the chemical and physical properties of concrete. Magazine of Concrete Research, Londres, Reino Unido, v. 63, n. 5, p. 313-320, 2011. Disponível em: https://doi.org/10.1680/macr.10.00019. Acesso em: 17 aug. 2020. 
ADEMOLA, S. A.; BUARI, T. A. Behaviour of bamboo leaf ash blended cement concrete in sulphates environment. IOSR Journal of Engineering, Gurugram, Índia, v. 4, n. 6, p. 01-08, 2014. Disponível em: https://doi.org/10.9790/3021-04610108. Acesso em: 17 aug. 2020.

ALTUN, F.; AKTAŞ, B. Investigation of reinforced concrete beams behavior of steel fiber added lightweight concrete. Construction and Building Materials, Amsterdan, Países Baixos, v. 38, p. 575-581, 2013. Disponível em: https://doi.org/10.1016/j.conbuildmat.2012.09.022. Acesso em: 17 aug. 2020.

AMARAL, M. C. Avaliação dos efeitos da incorporação de resíduo de lama de cal naspropriedades e microestrutura de uma mistura solo-cimento. 2016. 100 p. Tese (Doutorado em Engenharia e Ciência dos Materiais) - Universidade Estadual do Norte Fluminense, Campos dos Goytacazes, 2016.

AMERICAN SOCIETY FOR TESTING AND MATERIALS. ASTM C1709 - 18: standard guide for evaluation of alternative supplementary cementitious materials (ASCM) for use in concrete. West Conshohocken, EUA: ASTM International, 2018.

AMERICAN SOCIETY FOR TESTING AND MATERIALS. ASTM C618-19. Standard specification for coal fly ash and raw or calcined natural pozzolan for use in concrete. West Conshohocken, EUA: ASTM International, 2019.

AMIN, M. N. et al. Pozzolanic potential and mechanical performance of wheat straw ash incorporated sustainable concrete. Sustainability, Basel, Suíça, v. 11, n. 2, p. 1-20, 2019. Disponível em: https://doi.org/10.3390/su11020519. Acesso em: 17 aug. 2020.

ARUM, C.; IKUMAPAYI, C. M.; ARALEPO, G. O. Ashes of biogenic wastes: pozzolanicity, prospects for use, and effects on some engineering properties of concrete. Materials Sciences and Applications, Wuhan, China, v. 4, n. 9, p. 521-527, 2013. Disponível em: https://doi.org/10.4236/msa.2013.49064. Acesso em: 17 aug. 2020.

ARVANITI, E. C. et al. Physical characterization methods for supplementary cementitious materials. Materials and Structures/Materiaux et Constructions, Lonres, Reino Unido, v. 48, p. 3675-3686, 2015. Disponível em: https://doi.org/10.1617/s11527-014-0430-4. Acesso em: 17 aug. 2020.

ASSOCIAÇÃO BRASILEIRA DE NORMAS TÉCNICAS. NBR 12653. Materiais pozolânicos - requisitos. Rio de Janeiro: [s. n.], 2014.

CARVALHO, Y. M. Do velho ao novo: a revisão de literatura como método de fazer ciência. Revista Thema, Pelotas, Rio Grande do Sul, v. 16, n. 4, p. 913-928, 2019. Disponível em: https://doi.org/http://dx.doi.org/10.15536/thema.V16.2019.913-928.1328. Acesso em: 17 aug. 2020.

CHEN, H. et al. An approach for predicting the compressive strength of cement-based materials exposed to sulfate attack. PLoS ONE, São Franciso, EUA, v. 13, n. 1, p. 1-17, 2018. Disponível em: https://doi.org/10.1371/journal.pone.0191370. Acesso em: 17 aug. 2020.

COLLIN, B. et al. Distribution and variability of silicon, copper and zinc in different bamboo species. Plant and Soil, Londres, Reino Unido, v. 351, n. 1-2, p. 377-387, 2012. Disponível 
em: https://doi.org/10.1007/s11104-011-0974-9. Acesso em: 17 aug. 2020.

CORDEIRO, G. C.; SALES, C. P. Pozzolanic activity of elephant grass ash and its influence on the mechanical properties of concrete. Cement and Concrete Composites, Amsterdan, Países Baixos, v. 55, p. 331-336, 2015. Disponível em: https://doi.org/10.1016/j.cemconcomp.2014.09.019. Acesso em: 17 aug. 2020.

CORDEIRO, G. C.; TOLEDO FILHO, R. D.; FAIRBAIRN, E. M. R. Effect of calcination temperature on the pozzolanic activity of sugar cane bagasse ash. Construction and Building Materials, Amsterdan, Países Baixos, v. 23, n. 10, p. 3301-3303, 2009. Disponível em: https://doi.org/10.1016/j.conbuildmat.2009.02.013. Acesso em: 17 aug. 2020.

CROW, J. The concrete conundrum. Chemistry World, Londres, Reino Unido, p. 62-64, 2008.

DAMINELI, B. L.; PILLEGGI, R. G.; JOHN, V. M. Influence of packing and dispersion of particles on the cement content of concretes. Revista IBRACON de Estruturas e Materiais, São Paulo, v. 10, n. 5, p. 998-1024, 2017. Disponível em: https://doi.org/10.1590/s198341952017000500004. Acesso em: 17 aug. 2020.

DAMTOFT, J. S. et al. Sustainable development and climate change initiatives. Cement and Concrete Research, Amsterdan, Países Baixos, v. 38, n. 2, p. 115-127, 2008. Disponível em: https://doi.org/10.1016/j.cemconres.2007.09.008. Acesso em: 17 aug. 2020.

DAVID, N. L.; HASSAN, L. K. Physical and mechanical properties of cement mortar using lime and bamboo-ash as partial replacements. Malaysian Journal of Civil Engineering, Johor Bahru, Malásia, v. 30, n. 2, p. 254-268, 2018. Acesso em: 17 aug. 2020.

DHENGARE, S. et al. Fineness effect of sugarcane bagasse ash, rice husk ash, and fly ash on strength of concrete. International Research Journal of Engineering and Technology, Hyderabad, Índia, v. 6, n. 2, p. 121-126, 2019. Acesso em: 17 aug. 2020.

DHINAKARAN, G.; CHANDANA, G. H. Compressive strength and durability of bamboo leaf ash concrete. Jordan Journal of Civil Engineering, Irbid, Jordânia, v. 10, n. 3, p. 279289, 2016. Disponível em: https://doi.org/10.14525/jjce.10.3.3601. Acesso em: 17 aug. 2020.

DUCHESNE, J. Alternative supplementary cementitious materials for sustainable concrete structures: a review on characterization and properties. Waste and Biomass Valorization, n. 0123456789, 2020. Disponível em: https://doi.org/10.1007/s12649-020-01068-4. Acesso em: 17 aug. 2020.

DWIVEDI, V. N. et al. A new pozzolanic material for cement industry: bamboo leaf ash. International Journal of Physical Sciences, v. 1, n. 3, p. 106-111, 2006.

FRÍAS, M. et al. Characterization and properties of blended cement matrices containing activated bamboo leaf wastes. Cement and Concrete Composites, Amsterdan, Países Baixos, v. 34, n. 9, p. 1019-1023, 2012. Disponível em: https://doi.org/10.1016/j.cemconcomp.2012.05.005. Acesso em: 17 aug. 2020.

HABEEB, G. A.; MAHMUD, H. B. Study on properties of rice husk ash and its use as cement replacement material. Materials Research, v. 13, n. 2, p. 185-190, 2010. 
HEIRI, O.; LOTTER, A. F.; LEMCKE, G. Loss on ignition as a method for estimating organic and carbonate content in sediments: reproducibility and comparability of results. Journal of Paleolimnology, v. 25, p. 101-110, 2001.

HELANDER, M. et al. Endophytic fungi and silica content of different bamboo species in giant panda diet. Symbiosis, v. 61, n. 1, p. 13-22, 2013. Disponível em: https://doi.org/10.1007/s13199-013-0253-z. Acesso em: 17 aug. 2020.

HIDALGO-LÓPEZ, O. Bamboo: the gift of the gods. Bogotá, Colombia: The author, 2003.

IKEAGWUANI, C. C. et al. Potential of bamboo stem ash as aupplementary cementitious material in concrete production. International Journal of Engineering Research \&Technology, v. 8, n. 08, p. 75-80, 2019.

IKUMAPAYI, C. M. Crystal and microstructure analysis of Pozzolanic properties of bamboo leaf ash and locust beans pod ash blended cement concrete. Journal of Applied Sciences and Environmental Management, v. 20, n. 4, p. 943, 2017. Disponível em: https://doi.org/10.4314/jasem.v20i4.6. Acesso em: 17 aug. 2020.

JAYA, R. P. et al. Properties of mortar containing rice husk ash at different temperature and exposed to aggressive environment. Advanced Materials Research, v. 620, p. 87-93, 2013. https://doi.org/10.4028/www.scientific.net/AMR.620.87. Acesso em: 17 aug. 2020.

KAZA, S. et al. What a waste 2.0: a global snapshot of solid waste management to 2050 . Washington: International Bank for Reconstruction and Development/The World Bank, 2018.

KOLAWOLE, J. T.; OLUSOLA, K. O.; ATA, O. Strength of bamboo leaf ash and pulverized burnt clay waste blended cement concrete. IOSR Journal of Mechanical and Civil Engineering Ver. II, v. 12, n. 6, p. 36-42, 2015. Disponível em: https://doi.org/10.9790/1684-12623642. Acesso em: 17 aug. 2020.

LIAN, C.; ZHUGE, Y.; BEECHAM, S. The relationship between porosity and strength for porous concrete. Construction and Building Materials, Amsterdan, Países Baixos, v. 25, n. 11, p. 4294-4298, 2011. Disponível em: https://doi.org/10.1016/j.conbuildmat.2011.05.005. Acesso em: 17 aug. 2020.

LIBRE, N. A. et al. Mechanical properties of hybrid fiber reinforced lightweight aggregate concrete made with natural pumice. Construction and Building Materials, Amsterdan, Países Baixos, v. 25, n. 5, p. 2458-2464, 2011. Disponível em:

https://doi.org/10.1016/j.conbuildmat.2010.11.058. Acesso em: 17 aug. 2020.

LUHAR, S.; CHENG, T. W.; LUHAR, I. Incorporation of natural waste from agricultural and aquacultural farming as supplementary materials with green concrete: a review. Composites Part B: Engineering, Amsterdan, Países Baixos, v. 175, n. March, p. 107076, 2019.

Disponível em: https://doi.org/10.1016/j.compositesb.2019.107076. Acesso em: 17 aug. 2020.

MA, J. F.; TAKAHASHI, E. Soil, fertilizer, and plant silicon research in Japan. 1. ed. Amsterdam, Países Baixos: Elsevier Scinece B.V., 2002.

MARTIRENA, F.; MONZÓ, J. Vegetable ashes as supplementary cementitious materials. Cement and Concrete Research, Amsterdan, Países Baixos, v. 114, p. 57-64, August, 2018. 
Disponível em: https://doi.org/10.1016/j.cemconres.2017.08.015. Acesso em: 17 aug. 2020.

MASSAZZA, F. Pozzolanic cements. Cement and Concrete Composites, Amsterdan, Países Baixos, v. 15, n. 4, p. 185-214, 1993. Disponível em: https://doi.org/10.1016/09589465(93)90023-3. Acesso em: 17 aug. 2020.

MEHTA, P. K.; MONTEIRO, P. J. M. Concrete: microstructre, properties, and materials. 3. ed. [s. l.]: The McGraw-Hill Companies, Inc., 2006.

MEMON, S. A. et al. Environmentally friendly utilization of wheat straw ash in cementbased composites. Sustainability (Switzerland), v. 10, n. 5, p. 1-21, 2018. Disponível em: https://doi.org/10.3390/su10051322. Acesso em: 17 aug. 2020.

MO, K. H. et al. Green concrete partially comprised of farming waste residues: a review. Journal of Cleaner Production, Amsterdan, Países Baixos, v. 117, p. 122-138, 2016. Disponível em: https://doi.org/10.1016/j.jclepro.2016.01.022. Acesso em: 17 aug. 2020.

MOOSBERG-BUSTNES, H.; LAGERBLAD, B.; FORSSBERG, E. The function of fillers in concrete. Materials and Structures, v. 37, n. 2, p. 74-81, 2004. Disponível em: https://doi.org/10.1007/bf02486602. Acesso em: 17 aug. 2020.

MORAES, M. J. B. et al. Production of bamboo leaf ash by auto-combustion for pozzolanic and sustainable use in cementitious matrices. Construction and Building Materials, Amsterdan, Países Baixos, v. 208, p. 369-380, 2019. Disponível em: https://doi.org/10.1016/j.conbuildmat.2019.03.007. Acesso em: 17 aug. 2020.

MOSLEY, S. All About Bamboo Plants: how to grow a bambooplant. [s. l.]: Lulu Press Inc., 2013.

MOTOMURA, H.; HIKOSAKA, K.; SUZUKI, M. Relationships between photosynthetic activity and silica accumulation with ages of leaf in Sasa veitchii (Poaceae, Bambusoideae). Annals of Botany, v. 101, n. 3, p. 463-468, 2008. Disponível em: https://doi.org/10.1093/aob/mcm301. Acesso em: 17 aug. 2020.

MUJEDU, K. A. et al. Evaluation of physical and mechanical properties of partially replaced bamboo ash cement mortar. The International Journal of Engineering and Science, v. 7, n. 3, p. 35-41, 2018. Disponível em: https://doi.org/10.9790/1813-0703013541. Acesso em: 17 aug. 2020.

MUJEDU, K. A.; ADEBARA, S. A.; LAMIDI, I. O. The use of corn cob ash and saw dust ash as cement replacement in concrete works. The International Journal Of Engineering And Science, v. 3, n. 4, p. 22-28, 2014. Disponível em: http://theijes.com/papers/v3i4/Version-1/D03401022028.pdf. Acesso em: 17 aug. 2020.

NAKANISHI, E. Y. et al. Investigating the possible usage of elephant grass ash to manufacture the eco-friendly binary cements. Journal of Cleaner Production, Amsterdan, Países Baixos, v. 116, p. 236-243, 2016. Disponível em:

https://doi.org/10.1016/j.jclepro.2015.12.113. Acesso em: 17 aug. 2020.

NATARAJAN, S.; KARUPPIAH, G. Hierarchical order of influence of mix variables affecting compressive strength of sustainable concrete containing fly ash, copper slag, silica 
fume, and fibres. The Scientific World Journal, v. 2014, p. 11, 2014. Disponível em: https://doi.org/10.1155/2014/646840. Acesso em: 17 aug. 2020.

NEVILLE, A. M. Propriedades dos agregados. In: Propriedades do concreto. 5 ed. Porto Alegre: Bookman, p. 111-189, 2016.

OLAFUSI, O.; OLUTOGE, F. A. Strength properties of corn cob ash concrete strength properties of corn cob ash concrete. Journal of Emerging Trends in Engineering and Applied Sciences, v. 3, n. 2, p. 297-301, 2012.

OLONADE, K. A.; JAJI, M. B.; ADEKITAN, O. A. Experimental comparison of selected pozzolanic materials. African Journal of Science, Technology, Innovation and Development, v. 9, n. 4, p. 381-385, 2017. Disponível em: https://doi.org/10.1080/20421338.2017.1327931. Acesso em: 17 aug. 2020.

OLUTOGE, F. A.; OLADUNMOYE, O. M. Bamboo leaf ash as supplementary cementitious material. American Journal of Engineering Research, v. 6, n. 6, p. 1-8, 2017.

ONIKEKU, O. et al. Evaluation of characteristics of concrete mixed with bamboo leaf ash. The Open Construction \& Building Technology Journal, v. 13, n. 1, p. 67-80, 2019. Disponível em: https://doi.org/10.2174/1874836801913010067. Acesso em: 17 aug. 2020.

RODIER, L. et al. Study of pozzolanic activity of bamboo stem ashes for use as partial replacement of cement. Materials and Structures/Materiaux et Constructions, v. 50, n. 1, 2017. Disponível em: https://doi.org/10.1617/s11527-016-0958-6. Acesso em: 17 aug. 2020.

RODIER, L. et al. Potential use of sugarcane bagasse and bamboo leaf ashes for elaboration of green cementitious materials. Journal of Cleaner Production, Amsterdan, Países Baixos, v. 231, p. 54-63, 2019. Disponível em: https://doi.org/10.1016/j.jclepro.2019.05.208. Acesso em: 17 aug. 2020.

ROSELLÓ, J. et al. Microscopy characterization of silica-rich agrowastes to be used in cement binders: bamboo and sugarcane leaves. Microscopy and Microanalysis, v. 21, n. 5, p. 1314-1326, 2015. Disponível em: https://doi.org/10.1017/S1431927615015019. Acesso em: 17 aug. 2020.

SHAFIQ, N. et al. Effects of sugarcane bagasse ash on the properties of concrete.

Proceedings of the Institution of Civil Engineers: Engineering Sustainability, v. 171, n. 3, p. 123-132, 2018. Disponível em: https://doi.org/10.1680/jensu.15.00014. Acesso em: 17 aug. 2020.

SILVA, C. et al. StArt. [s. l.]: Laboratório de Pesquisa em Engenharia de Software (LaPES), São Carlos, 2016.

SINGH, N. B. et al. Hydration of bamboo leaf ash blended Portland cement. Indian Journal of Engineering and Materials Sciences, v. 14, n. 1, p. 69-76, 2007.

TAMBICHIK, M. A. et al. Utilization of construction and agricultural waste in Malaysia for development of green concrete: a review. IOP Conference Series: Earth and Environmental Science, v. 140, p. 9, 2018. Disponível em: https://doi.org/10.1088/17551315/140/1/012134. Acesso em: 17 aug. 2020. 
THOMAS, M. Supplementary cementing materials in concrete. In: Supplementary

Cementing Materials in Concrete, v. 32, p. 1-181, 2013. Disponível em:

https://doi.org/10.1201/b14493.

UMEMURA, M.; TAKENAKA, C. Biological cycle of silicon in moso bamboo (Phyllostachys pubescens) forests in central Japan. Ecological Research, v. 29, n. 3, p. 501510, 2014. Disponível em: https://doi.org/10.1007/s11284-014-1150-5. Acesso em: 17 aug. 2020.

UMOH, A. A.; ODESOLA, I. Characteristics of bamboo leaf ash blended cement paste and mortar. Civil Engineering Dimension, v. 17, n. 1, p. 22-28, 2015. Disponível em: https://doi.org/10.9744/ced.17.1.22-28. Acesso em: 17 aug. 2020.

UMOH, A. A.; UJENE, A. O. Empirical study on effect of bamboo leaf ash in concrete. Journal of Engineering and Technology, Hyderabad, Índia, v. 5, n. 2, p. 71-82, 2014.

VANDANAPU, S. N.; KRISHNAMURTHY, M. Seismic performance of lightweight concrete structures. Advances in Civil Engineering, Londres, Reino Unido, p. 6, 2018. Disponível em: https://doi.org/10.1155/2018/2105784. Acesso em: 17 aug. 2020.

VASSILEV, S. V. et al. An overview of the chemical composition of biomass. Fuel, Amsterdan, Países Baixos, v. 89, n. 5, p. 913-933, 2010. Disponível em: https://doi.org/10.1016/j.fuel.2009.10.022. Acesso em: 17 aug. 2020.

VILLAR-COCIÑA, E. et al. Pozzolanic behavior of bamboo leaf ash: characterization and determination of the kinetic parameters. Cement and Concrete Composites, Amsterdan, Países Baixos, v. 33, n. 1, p. 68-73, 2011. Disponível em: https://doi.org/10.1016/j.cemconcomp.2010.09.003. Acesso em: 17 aug. 2020.

VILLAR-COCIÑA, E. et al. Pozzolanic characterization of cuban bamboo leaf ash: calcining temperature and kinetic parameters. Waste and Biomass Valorization, Londres, Reino Unido, v. 9, n. 4, p. 691-699, 2018. Disponível em: https://doi.org/10.1007/s12649-016-97418. Acesso em: 17 aug. 2020.

YADAV, A. L. et al. An overview of the influences of mechanical and chemical processing on sugarcane bagasse ash characterisation as a supplementary cementitious material. Journal of Cleaner Production, Amsterdan, Países Baixos, v. 245, p. 118854, 2020. Disponível em: https://doi.org/10.1016/j.jclepro.2019.118854. Acesso em: 17 aug. 2020.

\section{AUTHOR INFORMATION}

\section{Name: Yuri Mariano Carvalho}

E-mail: yuri.mariano@engenharia.ufjf.br

Curriculum lattes: http://lattes.cnpq.br/1982095463163692

Graduando em Engenharia Civil na Universidade Federal de Juiz de Fora e Técnico em Edificações pelo Instituto Federal de Educação, Ciência e Tecnologia do Sudeste e Minas Gerais - Campus Juiz de Fora. Participou do Programa de Educação Tutorial do Curso de Engenharia Civil da UFJF, onde desenvolveu atividades envolvendo toda a tríade acadêmica (ensino, pesquisa e extensão). Tem trabalhado os seguintes temas: corrosão em estruturas sanitárias, infraestrutura verde e educação em engenharia. 


\section{Name: Laura Ferreira Velasco}

E-mail: laura.velasco@engenharia.ufjf.br

Curriculum lattes: http://lattes.cnpq.br/1095118543957011

Mestranda em Engenharia Civil/Estruturas pela Universidade Estadual do Norte Fluminense Darcy Ribeiro e graduação em Engenharia Civil pela Universidade Federal de Juiz de Fora. Possui formação técnica em Agroindústria pelo Instituto Federal de Educação, Ciência e Tecnologia Fluminense - IF Fluminense. Possui interesse na área de Materiais de Construção. Participou do Programa de Educação Tutorial do Curso de Engenharia Civil da UFJF, onde desenvolveu atividades envolvendo toda a tríade acadêmica (ensino, pesquisa e extensão). 